\title{
Drug use by elderly inpatients of a philanthropic hospital
}

\author{
Rômulo Moreira dos Santos*, Ivana Maria Fechine Sette, Lindomar de Farias Belém
}

Departamento de Farmácia, Universidade Estadual da Paraíba

\begin{abstract}
The high incidence of chronic diseases in the elderly leads to increased intermittent drug therapies. The presence of concomitant diseases and prescriptions made out by various health professionals facilitate the practice of polypharmacy, the emergence of iatrogenic diseases, and therapeutic regimens that are inconvenient for patients. The present study was carried out among elderly patients hospitalized at the Hospital Care Foundation of Paraiba, Campina Grande, with the objectives of studying the consumption of drugs by these patients, noting the possible adverse drug reactions (ADR), drug interactions and the presence of high-risk drugs prescribed to this age group. The study had a descriptive and cross-sectional quantitative design and involved a sample of 65 patients accompanied by the Pharmacovigilance Centre of the hospital, from August 2009 to July 2010. Over $90 \%$ of the patients were on polypharmacy, and the possible ADR found were related to the gastrointestinal tract where the most frequent interactions were with cardiovascular drugs. Within the context of pharmacoepidemiology, pharmacists can contribute by improving the quality of life of patients and preventing unnecessary expense with erroneous and poorly evaluated treatments.
\end{abstract}

Uniterms: Elderly patients/drugs use. Polypharmacy. Drugs/adverse reactions. Drug interactions.

A elevada incidência de doenças crônicas na terceira idade induz ao aumento de terapias medicamentosas intermitentes. A presença de patologias concomitantes e prescrições elaboradas por diversos profissionais de saúde facilitam a prática da polifarmácia, surgimento de doenças iatrogênicas e esquemas terapêuticos pouco cômodos para o paciente. O estudo foi realizado junto aos pacientes idosos internados no Hospital da Fundação Assistencial da Paraíba (FAP), Campina Grande, com objetivo de estudar o consumo de medicamentos por estes pacientes, observando as possíveis reações adversas a medicamentos (RAM), interações medicamentosas apresentadas e a presença de medicamentos de alto risco prescritos para este grupo etário. A pesquisa foi descritiva e transversal, com abordagem quantitativa, constituída por uma amostra de 65 pacientes, acompanhados através do Centro de Farmacovigilância do hospital, no período de agosto de 2009 a julho de 2010 . Mais de $90 \%$ dos pacientes estavam sob polifarmácia, as possíveis RAM encontradas estavam mais relacionadas ao trato gastrintestinal e as interações foram mais frequentes com os medicamentos de ação cardiovascular. Dentro do contexto da farmacoepidemiologia, o profissional farmacêutico pode contribuir para a melhoria da qualidade de vida dos pacientes e evitar gastos desnecessários devido à terapêuticas errôneas e mal avaliadas.

Unitermos: Terceira Idade/uso de medicamentos. Polifarmácia. Medicamentos/reação adversa. Interação medicamentosa.

\section{INTRODUCTION}

With the advancement of medical care and improvement of infrastructure and urban sanitation over the past few decades, the demographic pyramid of Brazil has undergone significant changes in its structure. These changes are due to the rise in the over 60-year age-group, reduced

*Correspondence: R. M. Santos, Departamento de Farmácia, Universidade Estadual da Paraíba, Avenida das Baraúnas, 351, Bodocongó, 58.429-500 Campina Grande - PB, Brasil. E-mail: moreira-rms@hotmail.com birth and mortality rates, plus longer life expectancy at birth (OPAS, 2007).

In 2004 , the elderly represented $9.0 \%$ of the total population of the country and mortality stood at $58.4 \%$ (OPAS, 2007). According to statistics from the World Health Organization (WHO), in 2025, Brazil is set to have approximately 32 million people aged 60 or older (Brazil, 1999).

With ageing, a number of systems and organs begin to fail, contributing to the emergence of chronic diseases 
such as hypertension and Diabetes mellitus. Against this background, the elderly accounted for $9.5 \%$ of hospital admissions in the public health care system in 2005, and diseases of the circulatory, respiratory and digestive systems were the main causes of admissions (OPAS, 2007).

In the third age, pharmacokinetic changes are more apparent as a result of reduced intestinal absorption surface, plasma proteins, and changes in liver and kidney function, which favor the emergence of problems during the therapy administered (Barradas, 2005).

Polypharmacy or polypharmacotherapy occurs when five or more medicines are used in association, when the patient uses a drug they do not require, or upon use of one drug to treat the adverse effects of another (MedeirosSouza et al., 2007).

On average, according to the Brazil's National Treatment Formulary and based on studies conducted in Cuba, seniors aged 65 to 69 years use 13.5 prescription drugs per year, while those over 80 years can use 18.2 medicines/ year. The most consumed drugs are antihypertensive drugs, analgesics, anti-inflammatory drugs, sedatives and gastrointestinal preparations (Brazil, 2008; Guerra et al., 2002).

The practice of polypharmacy is dangerous for patients, in particular for the elderly, because it favors the emergence of adverse drug reactions (ADR), side effects, drug interactions, longer hospital stay, iatrogenic disease and may also lead to complications that induce the patient's death (Woor, Argüelles, 2007; Cedeño, et al., 2000).

Therefore, polypharmacy is a serious public health problem, which entails greater spending on public service health and medicines, and is not conducive to an improved quality of life of the population. It also hinders the process of access to drug treatment by the patient, which is an added complication for elderly patients due to their reduced sensory and cognitive functions (Guerra et al., 2002).

The Study of Drug Use (SDU) aims to reduce the intensity of undesirable effects produced by drug interactions as well as other negative responses related to the use of medicines through the monitoring of marketing, distribution, prescription, dispensing and use of medicines in society (Bittencourt, Cruz, Castilho, 2004).

Within the context of pharmacovigilance and proposals by pharmacotherapeutic follow-up studies, SDU for seniors seeks information to promote improved quality of life of patients and to provide data to devise pharmacotherapeutic employee profiles and to elucidate the emergence of adverse reactions and other problems related to drugs (Muñoz et al., 2007; FAF, 2006).

According to the WHO (2005), the ADR are "all unwanted and harmful effect of a medicinal product which occurs at doses normally used for the treatment of a disease or the modification of physiological function".

According to the Third Consensus of Granada on Problems related to Medicines (PRM) and Negative Outcomes associated to Medicines (RNM) (2007), the PRM occur when the use of medicines cause, or may cause, the appearance of negative outcomes associated with medication and health results in RNM are patient not suitable for the purpose of Pharmacotherapy, associated with the use or failure to use medicines.

In this vein, to better meet the needs arising in connection with the third age, Brazil's National Congress through Legal Opinion 1.301 concerning proposed Law $\mathrm{n}^{\circ} 57 / 2003$, adopts provisions concerning the status of the elderly, as stipulated in article $2^{\circ}$ : The elderly person enjoys all the rights inherent to human beings, without prejudice to the full protection of this law, ensuring them, by law or by other means, all opportunities and facilities for preservation of their physical and mental health as well as their moral, intellectual, spiritual and social improvement, under conditions of freedom and dignity (Brazil, 2003).

\section{MATERIAL AND METHODS}

A cross-sectional descriptive study with a quantitative approach in a random convenience sample of patients was conducted between August 2009 and July 2010.

Elderly in-patients (aged 60) of the medical clinic and out-patients of the surgical philanthropic hospital Foundation Assistance of Paraíba (FAP) in Campina Grande-PB were followed using methods of pharmacovigilance, where patient records were reviewed and interviews conducted with patients (active approach). The study was conducted at the Centre of Pharmacovigilance of the hospital, part of the network of Sentinel Hospitals of the National Agency of Sanitary Surveillance in Brazil.

The study was conducted by the pharmacovigilance group belonging to the institution, in partnership with the State University of Paraíba because the philanthropic teaching hospital is classified as medium-sized and has just one pharmacist who performs only the traditional activities of the hospital pharmacy.

For this monitoring, standard forms were employed to register variables related to clinical condition, personal details (age, gender, active diagnoses, length of stay), data on treatments employed and complaints presented by patients during hospitalization. Polypharmacy was considered for patients who used five or more concomitant medications.

Patients of both genders were included, irrespective of age, race or social class. Patients in a condition that hindered the collection of data, such as those intubated, 
mechanically-ventilated, unconscious or in an intensive care unit (ICU), or whose data from medical records were insufficient to complete the questionnaire, were excluded from the study.

For the detection of possible ADR, the algorithm Naranjo et al. (1981) was used. The algorithm employs ten questions and yields a score for classification of causality of ADR. Comorbidities were differentiated when there was a possible diagnosis in the patient charts.

The physical condition of the patients was graded according to the American Society of Anesthesiologists (ASA), designed to provide a common terminology and facilitate the tabulation of statistical data. Classification matches: ASA I - normally healthy patient, ASA II - Patient with mild systemic disease, ASA III - Patient with severe systemic disease, ASA IV - Patient with severe systemic disease that threatens life, ASA V - moribund patient (death in 24 hours with or without surgery) (Lema, 2002-modified).

For the classification of body mass index (BMI), the cut-off points defined by the World Health Organization (WHO 1997) were employed: eutrophic $\left(18.5-24.9 \mathrm{~kg} / \mathrm{m}^{2}\right)$; overweight $\left(25.0-29.9 \mathrm{~kg} / \mathrm{m}^{2}\right)$ and obese $\left(\geq 30 \mathrm{~kg} / \mathrm{m}^{2}\right)$.

Diagnostic findings were grouped according to the chapters of the 10th edition of the international classification of diseases (ICD 10) (WHO, 2003) and medicines, according to the Anatomical Therapeutic Chemical (ATC) Classification Index, indicated for use in SDU (Capellà, Laporte, 1993).

For classification of PRM, the criteria advocated by the Third Consensus of Granada (2007) were used. To determine the possible drug interactions found in the prescriptions, the Micromedex database and manual Stockley's drug interactions manual (2009), were used.

The quantitative variables were subjected to epidemiologically-based statistical analysis by building tables with averages, standard deviations, minimum and maximum values, and absolute and relative frequencies, with the aid of EPI INFO 3.5.1.

According to Resolution $n^{\circ} 196 / 96$ of Brazil's National Health Council, a free and informed consent, explaining the conditions and purpose of the survey was signed by researcher and research subjects. The project was approved by the Committee of Ethics in Research of the State University of Paraiba under CAAE number 4562.0.000.133-09.

\section{RESULTS AND DISCUSSION}

The sample comprised 65 patients, with 32 admitted to the surgical ward of the Outpatient clinic and 33 to the
Medical Clinic. Sixty-seven patients were excluded because of lack of data from medical records. Table I contains clinical and personal data of patients.

TABLE I - Clinical and Personal Characteristics of Patients

\begin{tabular}{|c|c|}
\hline Variables & $\%-\mathrm{SD}$ \\
\hline \multicolumn{2}{|l|}{ Gender } \\
\hline Male & $35.4 \%(\mathrm{n}=23)$ \\
\hline Female & $64.6 \%(n=42)$ \\
\hline $\begin{array}{l}\text { Age (years) (mean } \pm \text { standard } \\
\text { deviation) }\end{array}$ & $\begin{array}{l}72.47 \pm 8.37 y(\text { minimum } \\
60, \text { maximum } 89)\end{array}$ \\
\hline \multicolumn{2}{|l|}{ ASA $*$} \\
\hline 1 & $41.5 \%(n=27)$ \\
\hline 2 & $49.2 \%(n=32)$ \\
\hline 3 & $9.3 \%(n=6)$ \\
\hline \multicolumn{2}{|l|}{ BMI* } \\
\hline Eutrophic & $35.4 \%(n=23)$ \\
\hline Overweight & $46.2 \%(n=30)$ \\
\hline Obese & $18.4 \%(n=12)$ \\
\hline $\begin{array}{l}\text { Length of hospital stay } \\
\text { (days) (mean } \pm \text { SD) }\end{array}$ & $\begin{array}{c}7.21 \pm 7.56(\text { minimum } 1, \\
\text { maximum } 51)\end{array}$ \\
\hline $\begin{array}{l}\text { Number of active Diagnoses } \\
(\text { Mean } \pm \text { SD) }\end{array}$ & $\begin{array}{c}2.13 \pm 1.06 \text { (minimum } 1, \\
\text { maximum } 6)\end{array}$ \\
\hline $\begin{array}{l}\text { Number of medicines used } \\
(\text { Mean } \pm \text { SD) }\end{array}$ & $\begin{array}{c}7.20 \pm 2.24(\text { minimum } 2, \\
\text { maximum } 11)\end{array}$ \\
\hline \multicolumn{2}{|l|}{ Evolution } \\
\hline & $64.6 \%(n=42)$ \\
\hline $\begin{array}{l}\text { High } \\
\text { ICU* }\end{array}$ & $24.6 \%(\mathrm{n}=16)$ \\
\hline Death & $10.8 \%(n=7)$ \\
\hline $\begin{array}{l}\text { Use of medicinal products before } \\
\text { Hospitalization }\end{array}$ & Yes $-100 \%$ \\
\hline Allergic to any medicine & No $-100 \%$ \\
\hline
\end{tabular}

Campina Grande, 2010.

*ASA - American Society of Anesthesiologists; BMI - Body Mass Index; ICU - Intensive Care Unit

Drug-related problems are common among elderly patients who are discharged from the hospital and are using several drugs for their chronic diseases. Examples of drug-related problems include contraindications, interactions, adverse drug reactions and inefficacy of treatment (Ahmad et al., 2010).

Of patients, $64.6 \%$ were overweight or obese, corroborating the report of Buzzachera et al. (2008), where predominantly females presented this morbidity in the treatment group. All patients stated absence or unaware- 
ness of having an allergy to any drugs and all were already in use of a drug before the process of admission.

With respect to the number of medications administered to each patient, $92.3 \%(n=60)$ of in-patients were under polypharmacy. Polypharmacy, constituting a condition contributing to the emergence of adverse drug reactions (ADR), may have induced the possible reactions found in patients (Figure 1), as well as the relative length of stay (Medeiros-Souza et al., 2007). In the study by Ahmad et al. (2010), Amsterdam, the polypharmacy patients were rehospitalized more often.

The large number of associated drugs favors the emergence of adverse reactions and PRM/RNM, as verified by Correr et al. (2007), where $13.5 \%$ of the drugs used were inadequate and classified at high risk of RNM with regard to therapeutic safety. Similarly, Mosegui et al. (1999) observed that $17.0 \%$ of the drugs used by 634 patients were unsuitable for the elderly and $15.5 \%$ had some drug interactions.

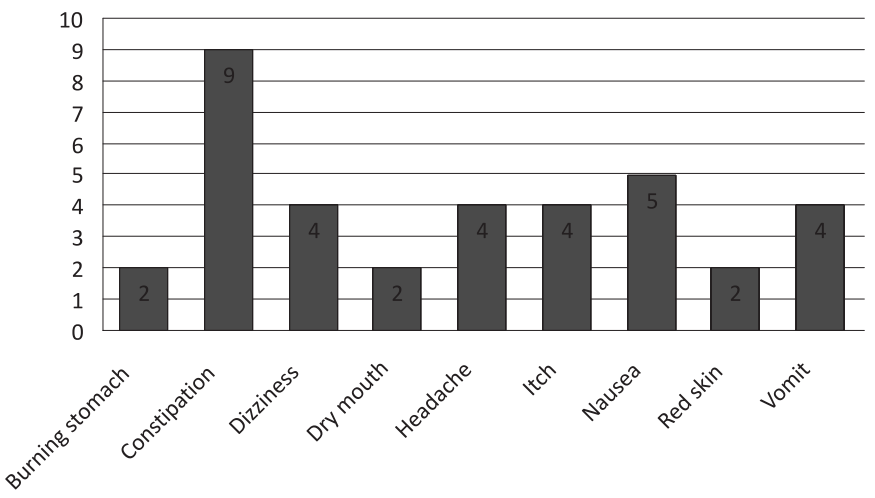

FIGURE 1 - Possible ADR found in the 65 patients studied. Campina Grande, 2010.

The 36 possible ADR found were related to the gastrointestinal tract, skin and the nervous system. Formiga, Jover and Mascaró (2001) found similar results in Spain regarding ADR, for emergence of complications during the hospital stay, but these differed as regards medicinal products administered.

In a study conducted in Germany, the drugs leading to ADR were used for hypertension, depression and inflammatory processes, and often involved use of herbal drugs containing Ginkgo biloba and Hypericum perforatum (Jeschke et al., 2010).

According to Routledge, O'Mahony and Woodhouse (2003), ADR are the cause of $6.7 \%$ of hospital admissions in the United States and $0.32 \%$ of ADR are fatal in patients. In the present study, no deaths were related to possible ADR.

The medicines used by patients suspected of causing ADR are shown in Figure 2. Table II contains the medicines administered during the hospital stay, ordered according to the Anatomical Therapeutic Chemical Code.

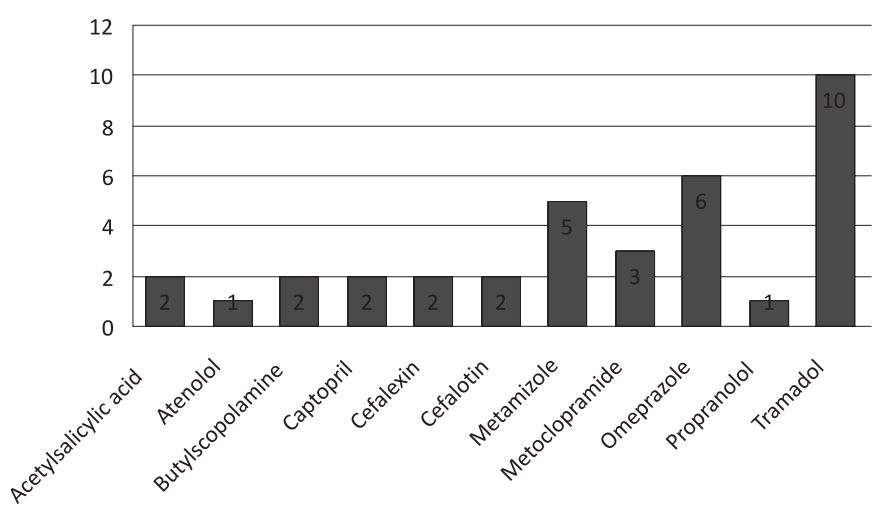

FIGURE 2 - Drugs suspected of causing ADR. Campina Grande, 2010.

TABLE II - Anatomical therapeutic chemical classification of medicinal products in accordance with the ATC

\begin{tabular}{llcc}
\hline $\begin{array}{l}\text { ATC } \\
\text { level 1 }\end{array}$ & Classification & $\mathrm{N}$ & $\%$ \\
\hline $\mathbf{A}$ & Digestive Tract and metabolism & 42 & 34.1 \\
$\mathbf{B}$ & Blood and Blood-forming organs & 02 & 1.6 \\
$\mathbf{C}$ & Cardiovascular system & 49 & 39.8 \\
$\mathbf{H}$ & Hormones, except sexual and insulin & 01 & 0.8 \\
$\mathbf{J}$ & Systemic Anti-infective agents & 11 & 8.9 \\
$\mathbf{N}$ & Nervous System & 17 & 13.8 \\
$\mathbf{P}$ & Antiparasitics & 01 & 0.8 \\
Total & & 123 & 100.0 \\
\hline
\end{tabular}

Campina Grande, 2010.

Of the 123 medicines reported, Furosemide (12.2\%), Glibenclamide (10.6\%) and Captopril (6.5\%) were the most prescribed medicines, due to the large number of patients with hypertension $(32.3 \%-\mathrm{n}=40)$, a chronic disease increasingly present in the elderly and young adults (Blasco, 2008). The high number of diagnoses of anemia $(19.6 \%-\mathrm{n}=21)$, diabetes and neoplasms was also noted, both with $n=9(7.3 \%)$.

The high rate of prescription of drugs that act on the cardiovascular, central nervous and digestive systems was also observed by Teixeira et al. (2008). Diagnostic findings during hospitalization are listed in Table III, ordered according to the chapters of ICD-10.

A total of 63 potential drug interactions were found on patient prescriptions, most frequent of which are shown in Table IV.

Acetylsalicylic acid (Aspirin) decreases diuretic action and increases the risk of digitalis poisoning, me- 
TABLE III - Classification of 124 active diagnoses according to chapters of ICD 10

\begin{tabular}{llll}
\hline Chapter ICD 10 & Classification & $\mathbf{n}$ & $\mathbf{\%}$ \\
\hline I & Infectious and parasitic diseases & 08 & $6.5 \%$ \\
II & Neoplasms & 10 & $8.1 \%$ \\
III & Diseases of blood and blood-forming organs and certain disorders & 22 & $17.7 \%$ \\
IV & involving immune mechanism & 09 & $7.3 \%$ \\
V & Endocrine, nutritional and metabolic diseases & 03 & $2.4 \%$ \\
VIII & Mental and behavioural disorders & 01 & $0.8 \%$ \\
IX & Diseases of ear and mastoid & 56 & $45.2 \%$ \\
$\mathbf{X}$ & Diseases of circulatory system & 04 & $3.2 \%$ \\
$\mathbf{X I}$ & Respiratory tract Diseases & 04 & $3.2 \%$ \\
$\mathbf{X I I I}$ & Digestive tract Diseases & 05 & $4.0 \%$ \\
XIV & Disease of Musculoskeletal system and & & $1.6 \%$ \\
Total & connective tissue & 02 & $\mathbf{1 0 0 . 0} \%$ \\
\hline Ca & Diseases of genitourinary system & $\mathbf{1 2 4}$ & $\mathbf{2}$ \\
\hline
\end{tabular}

Campina Grande, 2010.

tamizole decreases hypoglycemic effects, while some antihypertensive and anti-emetic agents, as well as concurrent use of inhibitors of angiotensin converting enzyme with potassium-sparing, increase the risk of hyperkalemia (Ibáñez et al., 2008; José et al., 2008).

The most common problems related to drugs (PRM) s, according to the Third Consensus of Granada (2007), were those concerning contraindications, double thera- peutic classes, and possible drug interactions likely to cause ADR.

Due to the potential of PRM to cause negative responses associated with medication (RNM), they represent a serious public health problem and should be avoided, since they further undermined the quality of life of hospitalized elderly patients in Spain (Santamaría-Pablos et al., 2009; Garcia et al., 2008).

TABLE IV - Most frequent possible drug interactions in prescriptions of elderly patients

\begin{tabular}{lccc}
\hline Drug Interaction & $\mathrm{n}$ & $\%$ & Possible Effect \\
\hline Aspirin + Furosemide & 01 & $3.3 \%$ & Decreases diuretic action \\
Captopril + Digoxin & 03 & $10.0 \%$ & Increases risk of digitalis poisoning \\
Captopril + Metamizole & 04 & $13.3 \%$ & Decreases ACE* inhibitor action \\
Captopril + Spironolactone & 03 & $10.0 \%$ & Increases risk of hyperkalemia \\
Caverdilol + Spironolactone & 01 & $3.3 \%$ & Increases risk of hyperkalemia \\
Clonidine + Diazepam & 01 & $3.3 \%$ & Increases risk of accident \\
Digoxin + Furosemide & 04 & $13.3 \%$ & Increases risk of digitalis poisoning \\
Digoxin + Hydrochlorothiazide & 01 & $3.3 \%$ & Increases risk of digitalis poisoning \\
Insulin + Furosemide & 02 & $6.7 \%$ & Decreases hypoglycemic effect \\
Metamizole + Glibenclamide & 03 & $10.0 \%$ & Decreases hypoglycemic effect \\
Metamizole + Insulin & 04 & $13.3 \%$ & Decreases hypoglycemic effect \\
Metamizole + Metoclopramide & 03 & $10.0 \%$ & Increases rate of analgesic absorption \\
Total & 30 & $100.0 \%$ & \\
\hline Sorce: Microl
\end{tabular}

Source: Micromedex Database, Stockley's Drug Interactions (2009) - Campina Grande, 2010

*ACE - angiotensin converting enzyme 
TABLE V - Medicines with potentially high risk for elderly patients

\begin{tabular}{lccc}
\hline MEDICINE & $\mathrm{n}$ & $\%$ & RISK \\
\hline Aminoglycosides & 1 & $9.7 \%$ & $\begin{array}{c}\text { Ototoxic and nephrotoxic potential, Neurotoxic } \\
\text { potential }\end{array}$ \\
$\begin{array}{l}\text { Amikacin } \\
\text { Gentamicin }\end{array}$ & 3 & & $\begin{array}{c}\text { Increases risk of falls and bone fractures and } \\
\text { Sedative Agents }\end{array}$ \\
$\begin{array}{l}\text { Diazepam } \\
\text { Clonazepam }\end{array}$ & 1 & $7.2 \%$ & Raytime sedation, by having long half-life in elderly \\
Bromazepam & 1 & & Risk of causing agranulocytosis \\
\hline $\begin{array}{l}\text { Nonsteroidal anti-inflammatory drugs } \\
\text { Metamizole }\end{array}$ & 7 & $17.2 \%$ &
\end{tabular}

Cardiovascular Agents

$\begin{array}{lll}\text { Digoxin } & 6 & 14.6 \%\end{array}$

Due to decreased renal debugging and loss of

$14.6 \%$ muscle mass, there is greater risk of causing digitalic poisoning

\begin{tabular}{lccc} 
Methyldopa & 3 & $7.3 \%$ & $\begin{array}{c}\text { Methyldopa can cause bradycardia and exacerbate } \\
\text { and/or induce depression }\end{array}$ \\
\hline $\begin{array}{l}\text { Diuretics } \\
\text { Hydrochlorothiazide }\end{array}$ & 4 & $44.0 \%$ & $\begin{array}{c}\text { By increasing night-time diuresis, the risk of falls } \\
\text { and fractures is increased }\end{array}$ \\
$\begin{array}{l}\text { Furosemide } \\
\text { TOTAL }\end{array}$ & 14 & $100.0 \%$ & \\
\hline
\end{tabular}

Source: Pereira et al., 2008 - Campina Grande, FAP, 2010.

The prescribed drugs having a potentially high risk for elderly patients are cited in Table V.

\section{CONCLUSIONS}

Even during short periods of hospitalization, more careful assessment is required when making out prescriptions in order to prevent drug-related complications, which have a negative impact on the health of elderly patients. This is especially important in this group which is psychologically vulnerable and often in an unfamiliar environment without the presence of relatives or acquaintances.

The Adverse Drugs Reactions and drug interactions found were denoted possible, since the study was not a follow-up on drug use, for which an appropriate methodology would be required.

The pharmacist as a health promoter must participate in the clinical monitoring, assessment and guidance of the therapy prescribed, interacting with others professionals toward improving the quality of life of this patient group.

\section{REFERENCES}

AHMAD, A.; HUGTENBURG, J.; WELSCHEN, L.M.C.; DEKKER, J.M.; NIJPELS, G. Effect of medication review and cognitive behavior treatment by the community of pharmacists of patients discharged from the hospital on drug related problems and compliance: design of a randomized controlled trial. BMC Public Health, v.10, n.133, p.1-10, 2010 .

BARRADAS, U.B. La prescrición en el anciano: cuidado con la polifarmacia y los efectos adversos. Rev. Hosp. Jua. Mex., v.72, n.1, p.18-22, 2005.

BAXTER, K. Stockley's drug interactions pocket companion. London: Pharmaceutical Press, 2009. p.471.

BITTENCOURT, M.O.; CRUZ, M.S.; CASTILHO, S.R. Problemas com a utilização de medicamentos: estudo piloto em hospital psiquiátrico do Rio de Janeiro. Rev. Bras. Farm., v.85, n.2, p.37-39, 2004. 
BLASCO, S.A. Prescripción de fármacos em paciente geriátrico. Semin. Fund. Esp. Reumatol., v.9, n.4, p.207-218, 2008.

BRASIL. Ministério da Saúde. Conselho Nacional de Saúde. Diário Oficial da União. Portaria 1395/GM de 10 de dezembro de 1999. Política de Saúde do Idoso. Brasília: Ministério da Saúde, 1999. Anexo (Introdução). 24 p.

BRASIL. Ministério da Saúde. Departamento de Assistência Farmacêutica e Insumos Estratégicos. Formulário Terapêutico Nacional. Série B - Textos Básicos de Saúde. Brasília, 2008. 897 p.

BRASIL. Senado Federal. Congresso Nacional. Diário Oficial da União. Parecer $n^{\circ} 1.301$ de 2003, dispõe sobre o estatuto do idoso e dá outras providências. Brasília: Congresso Nacional, 2003. Disposições preliminares, Artigo $2^{\circ}$.

BUZZACHERA, C.F.; KRAUSE, M.P.; HELSANGEDY, H.M.; HALLAGE, T.; GRANATO, P.; KRINSKI, K.; CAMPOS, W.; SILVA, S.G. Prevalência de sobrepeso e obesidade geral em mulheres idosas da cidade de Curitiba - Paraná. Rev. Nutr., v.21, n.5, p.525-533, 2008.

CAPELLÀ D.; LAPORTE J.R. Métodos aplicados en estudios descriptivos de utilización de medicamentos. In: Laporte JR, Tognoni G, editors. Principios de epidemiología del medicamento. 2.ed. Barcelona: Ediciones Científicas y Técnicas, 1993. p.67-93.

CEDEÑO, A.M.R.; VÁZQUEZ, P.M.M.; LEÓN, J.L.F.; ENRIQUÉZ, M.Q. Determinación de polifarmacoterapia en pacientes geriátricos de un consultorio del médico de la familia en Cienfuegos. Rev. Cubana Farm., v.34, n.3, p.170-174, 2000.

CORRER, C.J. Riscos com problemas relacionados com medicamentos em pacientes de uma instituição geriátrica. Rev. Bras. Cien. Farm., v.43, n.1, p.55-62, 2007.

FORMIGA, F.; JOVER, A.; MASCARÓ, J. Reacciones adversas a medicamentos: más frecuentes en mayores de 65 años. Rev. Esp. Geriatr. Gerontol., v.36, n.4, p.241-242, 2001.

FORO DE ATENCIÓN FARMACÊUTICA - FAF. PRM y RNM: conceptos. Farmacéuticos, v.2, n.15, p.28-29, 2006.

GARCÍA, V.; MARQUINHA, I.; OLABARRI, A.; MIRANDA, G.; RUBIERA, G.; BAENA, M.I. Resultados negativos associados a la medicación em um servicio de emergências hospitalário. Farm. Hosp., v.32, n.3, p.157-162, 2008.
GUERRA, N.F.; ARMESTO, D.D.; HERNÁNDEZ, B.P; PÉREZ, A.R. Polifarmacia en el anciano. Acta Medica, v.10, n.1, p.1-11, 2002.

IBÁÑEZ, A.; ACALÁ, M.; GARCÍA, J.; PUCHE, E. Interacciones medicamentosas en pacientes de um servicio de medicina interna. Farm. Hosp., v.32, n.5, p.293-297, 2008.

JESCHKE, E.; OSTERMANN, T.; TABALI, M.; VOLLMAR, H.C.; KRÖZ, M.; BOCKELBRINK, A.; WIIT, C.M.; WILLICH, S.N.; MATTHES, H. Pharmacotherapy of elderly patients in everyday of anthroposophic medical practice: a prospective, multicenter observational study. BMC Geriatrics, v.10, n.48, p.1-13, 2010.

JOSÉ, V.C.; LOREDO, M.L.G.; MANZANO, F.P.; ORTEGA, A.I.G.; FERRER, M.A. Interacciones farmacológicas en población polimedicada. Aten. Primaria, v.40, n.11, p.581587, 2008.

LEMA, M.L. Using the ASA physical status classification may be risky business. ASA Newsletter, v.66, n.9, p.24, 2002.

MEDEIROS-SOUZA, P; SANTOS-NETO, L.L.; KUSANO, L.T.E.; PEREIRA, M.G. Diagnosis and control of polypharmacy in the elderly. Rev. Saúde Pública, v.41, n.6, p.1049-1053, 2007.

MOSEGUI, G.B.G.; ROSENFELD, S.; VERAS, R.P; VIANNA, C.M.M. Avaliação da qualidade do uso de medicamentos em idosos. Rev. Saúde Pública, v.33, n.5, p.437-444, 1999.

MUÑOZ, P.A; SANTOS, J.M.A; CORPAS, J.P.G.; CENGOTITABENGOA, I.A. Guia de Atención Farmacéutica. Seguimiento farmacoterapéutico y educación sanitária en pacientes de edad avanzada. Granada: Universidad de Granada, 2007. 161 p.

NARANJO, C.A.; BUSTO, U.; SELLERS, E.M.; SANDOR, P.; RUIZ, I.; ROBERTS, E.A.; JANECEK, E.A.; DOMEQ, C.; GREENBLAT, D.J. A method for estimating the probability of adverse drug reactions. Clin. Pharmacol. Ther, v.30, n.2, p.564-575, 1981.

ORGANIZAÇÃO MUNDIAL DA SAÚDE. OMS. CID-10: classificação estatística internacional de doenças e problemas relacionados à saúde. 9 ed. rev. São Paulo: Editora da Universidade de São Paulo, 2003. 1126 p. 
ORGANIZAÇÃO MUNDIAL DA SAÚDE. OMS. Departamento de Medicamentos Essenciais e Outros Medicamentos. A importância da Farmacovigilância. Monitorização da segurança dos medicamentos. Brasília: Organização Mundial da Saúde/Organização PanAmericana da Saúde, 2005. 48 p.

ORGANIZACIÓN PAN-AMERICANA DE LA SALUD. OPAS. Brasil. In: Salud en las Américas, 2007. Available at: http://www.paho.org/hia/archivosvol2/paisespor/Brazil\%20 Portuguese.pdf. Accessed on: 13 apr. 2010.

PEREIRA, G.J.S.; SETTE, I.M.F.; BELÉM, L.F.; SILVA JUNIOR, E.D.; OLIVEIRA, A.R.; BARBOSA, J.A.A. Estudo de utilização de medicamentos em clínica médica. Rev. Bras. Farm., v.89, n.3, p.267-271, 2008.

ROUTLEDGE, P.A.; O’MAHONY, M.S.; WOODHOUSE, K.W. Adverse Drug reactions in the Elderly Patients. $B r . J$. Clin. Pharmacol., v.52, n.2, p.121-126, 2003.

SANTAMARÍA-PABLOS, A.; REDONDO-FIGUERO, C.; BAENA, M.I.; FAUS, M.J.; TEJIDO, R.; ACHA, O.; NOVO, F.J. Resultados negativos associados a medicamentos como causa de ingresso hospitalário. Farm. Hosp., v.33, n.1, p.12-25, 2009.
TEIXEIRA, J.J.V.; CANO, F.G.; SANCHES, A.C.C.; CARNIEL, T.A.; SCHNEIDER, D.S.L.G. Inquérito farmacoepidemiológico de pacientes de meia idade e idosos em três comunidades de Cascavel, PR - Brasil. Verificação evolutiva do conhecimento terapêutico. Rev. Bras. Cienc. Farm., v.44, n.2, p.297-303, 2008.

TERCER CONSENSO DE GRANADA SOBRE PROBLEMAS RELACIONADOS CON MEDICAMENTOS (PRM) Y RESULTADOS NEGATIVOS ASOCIADOS A LA MEDICACIÓN (RNM), 2007, Granada. Grupo de Investigación en Atención Farmacéutica. Universidad de Granada. Grupo de Investigación en Farmacología. Fundación Pharmaceutical Care España. Sociedad Española de Farmacia Comunitaria. Ars. Pharm., v.48, n.1, p.5-17, 2007.

WOOR, R.M.P.; ARGÜELLES, R.A.F. Eventos adversos a medicamentos en ancianos atendidos en un servicio de medicina familiar en Nayarit, México. Rev. Cubana Farm., v.41, n.3, p.1-7, 2007.

WORLD HEALTH ORGANIZATION. Preventing and managing the global epidemic of obesity. Report of the World Health Organization Consultation of Obesity. Geneve; 1997. (WHO Technical Report Series, 894).

Received for publication on $03^{\text {rd }}$ November 2010 Accepted for publication on $20^{\text {th }}$ December 2010 